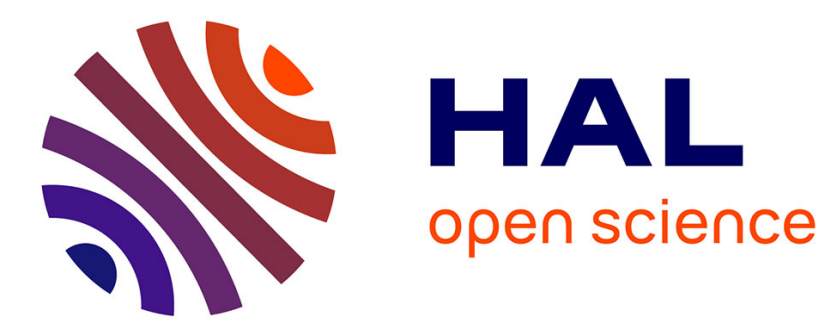

\title{
Book Review: Requiem for Communism
}

Magdalena Zolkos

\section{To cite this version:}

Magdalena Zolkos. Book Review: Requiem for Communism. European Journal of Cultural Studies, 2005, 8 (2), pp.267-268. 10.1177/1367549405051849 . hal-00571476

\section{HAL Id: hal-00571476 https://hal.science/hal-00571476}

Submitted on 1 Mar 2011

HAL is a multi-disciplinary open access archive for the deposit and dissemination of scientific research documents, whether they are published or not. The documents may come from teaching and research institutions in France or abroad, or from public or private research centers.
L'archive ouverte pluridisciplinaire HAL, est destinée au dépôt et à la diffusion de documents scientifiques de niveau recherche, publiés ou non, émanant des établissements d'enseignement et de recherche français ou étrangers, des laboratoires publics ou privés. 


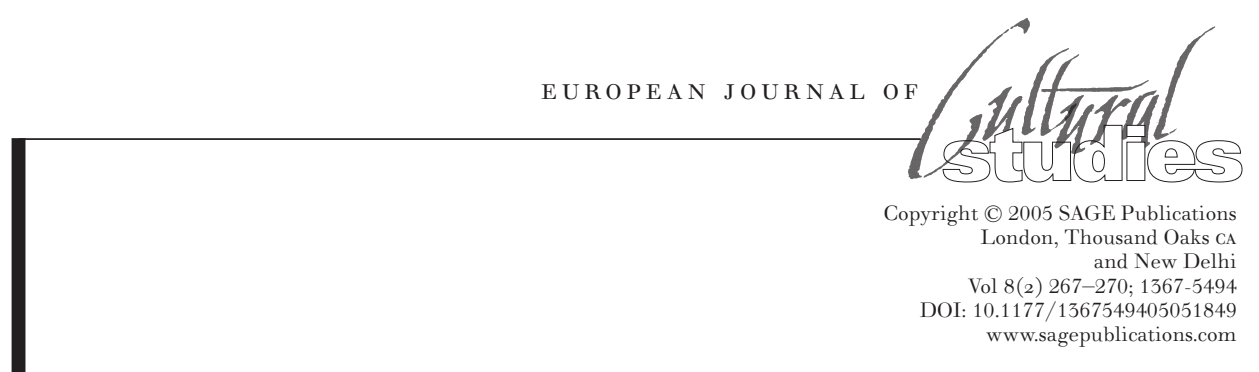

\section{Book reviews}

Charity Scribner, Requiem for Communism. Cambridge, MA: MIT Press, 2003. 245 pp. (inc. index). ISBN 0-262-19488-0 (hbk) \$34.95

Charity Scribner's book Requiem for Communism centres upon the question of how contemporary art has related to the post-communist transition and how, in this context, it has immersed into the politicized realms of East-European experience of collectivism, solidarity, loss and rejection. Contrary to the scepticism and ambivalence towards the political and cultural post-communist inheritance that has pervaded most of the 'views from outside', Requiem for Communism assumes that the East-European experience of transition bears a key to the understanding of our post-industrial and postmodern condition in general. It is hence primarily concerned with the 'aesthetic response to the socialist crisis' (p.9). The author recovers the meanings of communism and postcommunism through a critical inquiry into the dialectics of collective remembrance enclosed in contemporary literary texts, works of art and films. These are mapped subsequently into six different realms of the post-communist experience of a certain 'sense of dislocation' within the contemporary European environment, namely the collective, solidarity, nostalgia, mourning, melancholia and disavowal.

Requiem for Communism includes the inquiry into such important recent cultural acts as Sophie Calle's installation Die Entfernung (The Detachment); Andrzej Wajda's two chronicle films of the democratic opposition in Poland (The Man of Marble and The Man of Iron); Leslie Kaplan's novel L'Excès-l'usine (Factory Excess); John Berger's trilogy Into Their Labors; Mark Herman's film Brassed Off; and Christina Wolf's post1989 novels, etc. A noteworthy achievement of this book is that it positions these different works into a kind of a dynamic and prolific dialogue with each other so that they form an evocative and multifaceted discourse on collective post-communist memory. Requiem for Communism is thus of crucial interest not only for the scholars of the cultural and artistic dimension of the East-European transformations but also, more broadly, for those preoccupied with the rituals of mourning and transgression, the problematic of historical memory and psychoanalytical grasp of transitional justice and post-totalitarian reconciliation. 
In this context, Requiem for Communism pays a particular attention to the gender aspects of the post-communist cultural turn in that it analyses in the respective works of art the relationship between gender and sexuality on the one hand, and the collective perceptions of labour and socialism on the other. Through the problematization of the different dimensions of gender, the author demonstrates the complexity and tensions between people's private and public identities in Eastern Europe which, with the demise of communism, are being continuously renegotiated and redefined. The female figures in many of the studied works epitomize the transformation from nostalgia, through bereavement into abjuration, which the author describes as central for the East-European postcommunist remembrance. All in all, Requiem for Communism is an attention-grabbing and thought-provoking book, which indeed achieves what the author hopes for, namely 'open[ing] new lines of inquiry' into the collective history of post-communism.

\author{
Magdalena Zolkos \\ Copenhagen University
}

Noël Valis, The Culture of Cursilería: Bad Taste, Kitsch and Class in Modern Spain. Durham, NC: Duke University Press, 2002. xvi +406 pp. (inc. index). ISBN 0-8223-3000-8 (hbk) \$74.95; 0-8223-2997-2 (pbk) $\$ 24.95$

Cursilería or cursi-ness is a close relative of kitsch, but Noël Valis stresses the need to distinguish between them. Although both connote imitativeness and inauthenticity, kitsch is a product of advanced industrialization and mass consumerism, and as such does not become a pertinent category for Spanish cultural life until the 1960s. Cursi, on the other hand, is associated with the perception of belatedness and insufficient modernization, and while it persists as a meaningful category up to the present, it is in the transitional phase to a more full modernity, from the mid-19th century to the Civil War, that it plays a more prominent role as cultural signifier.

Valis warns us in the introduction that 'any definition of lo cursi is bound to be inadequate or reductive' (p. 17), and by the end of the book the reader will be left with no doubt about the truth of her assertion. My dictionary gives as possible English equivalents of cursi 'pretentious', 'showy', 'affected', 'genteel' and 'snobbish'. As a form of bad taste associated with marginality or inadequateness, cursilería has been perceived variously as vulgar, obsolete, feminine, provincial or foreign. But a more full understanding of the term comes from the awareness of its origins in 268 the social and cultural aspirations and anxieties of the middle class, and 